\title{
A review on the prevailing gaps in women's sexual and reproductive health rights in Tanzania's National Health Policy 2017
}

\section{Tinjauan tentang kesenjangan hak kesehatan seksual dan reproduksi perempuan dalam Kebijakan Kesehatan Nasional Tanzania 2017}

\author{
Emmanuel Michael Massay ${ }^{\bowtie}$ \\ ${ }^{1}$ Department of Gender Studies, The Mwalimu Nyerere Memorial Academy \\ Dar es Salaam, 9193, Tanzania \\ ${ }^{2}$ Department of Sociology, Faculty of Social and Political Sciences, Universitas Airlangga, \\ Surabaya, 60286, East Java Province, Indonesia \\ E-mail of corresponding author: emanuelmichael81@gmail.com
}

\begin{abstract}
Women's sexual and reproductive health rights (SRHR) are linked to numerous human rights; health, education, freedom from torture, protection from all forms of discrimination, and right of privacy. SRHR refers to a set of rights that every human being is entitled to, regardless of culture, race, religion, ethnicity, or disability. Women's sexual and reproductive health rights have been taken for granted, especially in Tanzania's health policies. However, Tanzania has several National Policies and Laws that affect women and men differently and in certain areas, they even contradict other existing laws. The prolonged poor SRHR shows the urgency of the reformation of the policies and laws. The analysis was carried out qualitatively through a reflection focused on the policy and other legal materials concerned. The study revealed that the policy does not cater enough for women's SRHR. This study concludes that the policies are outdated and have a lot of loopholes. This has led the sexual and reproductive health system in Tanzania astray. The study concludes that the TNHP 2017 has to be reviewed and revised in order to meet the women's SRHR and also to align it with some of the international policies and targets concerning sexual and reproductive health.
\end{abstract}

Keywords: health policy; sexual and reproductive health rights; women; gender-based violence

Abstrak

Hak kesehatan seksual dan reproduksi perempuan (SRHR) terkait dengan berbagai hak asasi manusia; kesehatan, pendidikan, kebebasan dari penyiksaan, perlindungan dari segala bentuk diskriminasi, dan hak privasi. SRHR mengacu pada seperangkat hak yang menjadi hak setiap manusia, terlepas dari budaya, ras, agama, etnis, atau kecacatan. Hak kesehatan seksual dan reproduksi perempuan telah diterima begitu saja, terutama dalam kebijakan kesehatan Tanzania. Namun, Tanzania memiliki beberapa Kebijakan dan Hukum Nasional yang mempengaruhi perempuan dan laki-laki secara berbeda dan di area tertentu, mereka bahkan bertentangan dengan hukum lain yang ada. Kasus SRHR yang buruk dan berkepanjangan menunjukkan urgensi reformasi kebijakan dan undang-undang. Analisis dilakukan secara kualitatif melalui refleksi yang difokuskan pada kebijakan dan bahan hukum lain yang bersangkutan. Studi tersebut mengungkapkan bahwa kebijakan tersebut tidak cukup melayani SRHR perempuan. Studi ini menyimpulkan bahwa kebijakan tersebut sudah ketinggalan zaman dan memiliki banyak celah. Hal ini telah menyesatkan sistem kesehatan seksual dan reproduksi di Tanzania. Studi tersebut menyimpulkan bahwa TNHP 2017 harus direview dan direvisi untuk memenuhi SRHR perempuan dan juga untuk menyelaraskannya dengan beberapa kebijakan dan target internasional terkait kesehatan seksual dan reproduksi.

Kata Kunci: kebijakan kesehatan; hak kesehatan reproduksi dan seksual; perempuan; kekerasan berbasis gender

\section{Introduction}

Tanzania is one of the countries struggling to improve its health system, and one way to do that is through good policies that are strategically upright, attainable, inclusive, and sustainable. Tanzania has several noble shaped policies in place, in the health category Tanzania has its National Health Policy of 2017 which its foremost vision is the improvement of the health and wellbeing of Tanzanians especially those who are at greater risks. Additionally, to structure the health system so as it becomes more obliging to the demands of the Tanzanian's. However, the policy mission is to simplify the delivery of unbiased, quality, and at the same time inexpensive primary health facilities (MOHCDGEC 2017). The National Health Policy carries a lot of importance toward reaching development in the health sector of any country. The Health Policies are referred to as a torch guiding the advancement of the health sector in particular and development in general. In a country like Tanzania where the resources are limited, it's imperative to formulate and reformulate good health policies for its people. This study aims to expose the gaps available in SRHR within the TNHP (Tanzania's National Health Policy) of 2017, so as to reveal the urgency of issues that need to be addressed as early as possible. 
The TNHP (Tanzania's National Health Policy) 2017 has a set of quality hence well-structured strategies which if are well implemented they will assist the improvements of the health and wellbeing of the Tanzanians and assist the realization of SRHR. The better health strategies has a direct impact to the individuals and at the same time to the nation's development in general but accountability is key. Boydell et al. (2019) set out to express the importance of accountability in the overall achievement of SRHR. Being accountable in SRHR is important for its attainment and it is shaped by a series of accountability connections (Boydell et al. 2019; Global Health Workforce Alliance 2013).

The problems with the TNHP (Tanzania's National Health Policy) 2017 has been the gaps prevailed and also the failure to the implementations of the targets in place. Some of the plans, targets, and agreements remain in papers due to poor budget allocation and bureaucratic nature of in some of the offices. For instance, in health promotion the TNHP (Tanzania's National Health Policy) 2017 aimed to promote better health through providing enough education with a particular focus on specific diseases which are linked with SRHR such as; HIV/AIDS, and Malaria. Issues like prevention education, and nutrition education were at the forefront of the agenda. Where the ways of promotion included dissemination, sensitization and advocacy, well informed community participation, and understanding the role of nutrition in wellbeing. However gender-based violence (GBV), all together with the violence against children (VAC) remains as two major constrain, it is said that in 2015 to $201640 \%$ and $17 \%$ of women 15-49 years have come across physical or sexual violence. Also, 8 percent of pregnant women reported experiencing violence during pregnancy (MOHCDGEC 2017). Maternal mortality rates have been witnessed as the other constrain to SRHR in Tanzania and it needs an extra eye. According to Tull (2019) and Tull (2020) maternal mortality rate and child mortality rates are tallying differently in Tanzania. While the child mortality rate is experiencing a reduction in the latest years maternal mortality rate is still stagnant (Tull 2019;2020). All these shortcomings are the results of the poor implementation of the policy strategies. When it comes to the application to family planning it still has been a challenge up to now due to some myths, and misconceptions hence little male involvement.

It has to be remembered that this first Policy is a revised edition of the 1990 Health Policy, which emphasizes adding up community participation in the development of health parameters, with enhanced access to health and health services. To solve the above-mentioned challenges, in the revision of this particular policy, the health ministry established collaborative efforts. Besides, the 2025 Tanzania Development Vision has identified health as one of the main concerns among others. One of its main focuses is to achieve high-quality livelihood for all Tanzanians. This is anticipated to be achieved through policies that will guide the attainment of some of the SRHR. These two health services emphasize directly the easy attainment of the SRHR and care: - Starting with the reduction of infant and maternal mortality rates by three-quarter of the current level; and also, reaching Gender equality and women empowerment in all health reflections.

SRHR referred to a group of rights that are in place to cover both wellbeing and sexual concerns without any biases. These rights may be associated with; pregnancy, maternal mortality, adolescents, abortion, HIV/AIDS, harmful traditional practices, GBV, family planning, and contraception. Factors such as; culture, race, religion, ethnicity, or disability may not be the blockage toward enabling access to these rights. SRHR gives one's power to pick and make a well-informed decision when it comes to sexuality and reproduction. When sexual and reproductive health rights are violated, it means that the affected people lack control over their bodies in terms of fertility, sexuality, and relationships and that the individuals are not allowed to consider their own choices and decisions, as the choices have already been set, for instance; my family, laws, or norms and values of a certain society (Darroch et al. 2001). It is imperative to the realization that SRHR does not involves only the absence of reproductive and sexual concerns, but also the total well-being of sexual health (Turshen \& Turshen 2020).

Worldwide, poor SRHR is a contributor to high mortality rates, according to Alemu \& Fantahun, 2011 approximately one-third of the global challenges of health and early mortality rates are among women especially the ones at the reproductive age. However, there is a direct association between SRHR and GBV, SRHR has always been considered GBV as its biggest obstacle. According to García-Moreno (2005) and Devries et al. (2010), the showing of lifetime GBV including physical violence and intimate partner violence is approximated to reach 15 percent, with the 28 percentage of women come across intimate partner violence in the pregnancy period (García-Moreno 2005; Devries et al. 2010). This also hasn't been different from the Tanzania perspective, According to MOHCDGEC 2017 gender-based violence and violence against children are still the major problems, noted that in the years 2015 to 2016 itself approximately 40 percentage and 17 percentage of women ranging from 15 to 49 years of age have come across sexual violence or physical violence. Also, 8 percent of pregnant women have been reported experiencing violence during the pregnancy period, this keeps the fight to reach quality SRHR more solid. 
Several studies have been tried to sightsee the GBV magnitude and its direct and indirect link with SRHR in Tanzania and to provide its cure. UNESCO (2013) indicates that the 2006 Human rights report of Tanzania reported that the Mara region is regarded as the place with the higher cases to be reported on GBV. This implies that the community is more likely to report the perpetrators to the police desks established and other responsible authorities. In Tanzania, as of recent, there are two surveys done in the country which resulted as a milestone on solving GBV. Firstly, the Tanzania Demographic and Health survey included a module on GBV and other forms of violence for the first time.

Secondly, the National survey specifically focusing on the violence against children which appeared to be one of its kind to be conducted in Africa it reveals petrifying data related to child violence in different regions. According to the Government of Sweden report on the "Strategy for sexual and reproductive health and rights (SRHR) in Sub-Saharan Africa" of 2006, cautioning that apart from all the positive developments reached by several countries in the region still many of them will not reach the Millennium Development Goals focusing on the child and maternal rate. The report added, the causes are the growth of the population HIV/AIDS, GBV, and VAC, gender inequality, low dimensions in health services and medicines, and also the continuous violence and civil wars in some of the regions (Government of Sweden 2016).

HIV/AIDS and SRHR are inseparable, however, HIV/AIDS is a killer in sub-Saharan Africa, sadly women and young girls are the ones who are in the frontline. Sundby (2016) reported that chlamydia is much higher in young women especially in developing countries. According to the Guttmacher Institute report, accounts that approximately every $7 \%$ of 15 young women aged between 24 years of age are already the victims of HIV/AIDS. Adding that this respective age is leading in the world when it comes to the new cases of HIV/AIDS, many country's health policies have not focused on this sexually energetic age group which makes it more a complex situation. A large number of young women are exposed to the environment of unplanned pregnancies and rapes. The issue of sex trafficking especially to young girls from rural to urban areas even out of borders is still untouchable, the use of contraceptives to those who need them is low, FGM still exists, and abortion is also a challenge (Sundby 2006).

Schaaf et al. (2020) suggest that in the time of crisis's SRHR is much needed and all the responsible urgencies are not paying attention by focusing on extra responses to the emergencies (Schaaf 2020). COVID-19 pandemic smashed many African countries hard and most of them caught unprepared financially, and health services-wise. When COVID-19 shook the world the SRHR are also traumatized, from diminishing the budget from its side and lessen implantation and accountabilities. As COVID-19 upsurges the mortality rates and so does SRHR, by considering the importance of SRHR in our social life and health in general SRHR cannot be disremembered especially during the time of tragedies. As far as the government is focusing on combating the disease the responsible authorities have to continue with the execution of strategies to diminish SRHR.

The study is specifically guided by the "Theory of gender discrimination", several theories in the field of social science have been guiding our awareness of inter-group relations with concerns to prejudice and discrimination. The distinct social context results in the recognition of particular group affiliation (in-group) and that can directly lead to the denial of some rights to the other group (out-group) directly or indirectly, it can also affect the sharing or the allocation of resources or services in the society. One of the theoretical perspective which outline this is the "social identity perspective". (Tajfel \& Turner 1986) states that members of the same affiliation are encouraged to defend their self-esteem hence achieving a positive and distinctive social character. The long for a positive social identification may result in discrimination to other groups, which is articulated as a direct or indirect mistreat to the out-group, this referred to as "in-group bias".

The fact that in the society on enjoys high status, access to opportunities, needs, and services than the other that signifies discrimination, and that invites the explanation that people are differentiated according to factors like sex, race, or culture. Discrimination in this study is discussed as it appears in the access to basic health services to SRHR. A person may contact discrimination in the perspective that whenever the decision is done one group is directly or indirectly left behind in the decision-making process concerning their health. However, discrimination passes in the society and harms equal access to different opportunities, and services such as SRHR, especially to women. Nonetheless, about SRHR and the policy, it's experiential that the vital needs which may affect the lives of women and girls have not been prioritized or well stipulated, and that is due to the prolonged patriarchal patterns from the policymakers to the grass-root level implementers. As proof that human beings tend to discriminate, the studies conducted by Tajfel and Turner, disclose how recognition in a particular group affiliation may result in in-group bias, the favoring of in-group members compared to the out-group members $I$ in the 
sense of evaluation and allocation of resources (Turner 1986). However, the TNHP 2017 highlighted that the priority will be provided to the vulnerable groups such as; women of reproductive age, infants, school children, youths, people with disability, under-fives, and elders group in which to some extent it has not been the case.

Tanzania is one of the countries located in the eastern part of Africa thus has recently been given the title of a lower-middle-income country. Tanzania was twisted into a sovereign state in 1964 after the unification of two states of Tanganyika and Zanzibar. The country has a coverage area of 947,000 Square Kilometers. And it has a population of 58 million people. As Tanzania has recently moved to the lowermiddle-income economy this provides a different picture and gives it a new challenge on its broad vision of development, and been expected as much as possible a total take off in the health sector respectively.

Meanwhile, Tanzania's health system has a lot of inefficiency, Tanzania suffers the outnumbered of SRHR hostiles indicators such as; high prevalence of HIV/AIDS, GBV, early and child marriages, VAC, and Intimate partner violence. It's with no doubt that the health sector needs reshuffling to meet the universal targets. However, the efforts have been made through the adaptation of health in all policies, a particular focus on the quality of the health services provided is vital. The country made such an impressive step in reducing under-five and infant mortality rates, by setting a particular emphasis on free access to immunization services. Nevertheless, the new cases of HIV/AIDS have marginally dropped down. However, Maternal Mortality Rate is a hindrance to the realization of the Millennium Development Goals (MDG) (MOHCDGEC 2017).

Cultural hindrances have also emerged to be a huge challenge to the realization of SRHR, through things like widow inheritance, widow cleansing, GBV, early marriages, female genital mutilation/cutting, and forced marriages SRHR has been suffocated. Tanzania has been battling cultural hindrances for a while now, customary laws and bad traditional practices. However, parent's absence of knowledge on SRHR interrelated issues in adolescents are also encountering (Ngilangwa et al. 2016; Yngheden \& Sandqvist 2019). In accessing healthcare services the privacy challenges are showing up, according to Nyblade et al. (2017) added that issues like probing, persuasion, questioning, about sexual partners, and being required to bring them when accessing care to the healthcare facilities are standing obstacles to accessing the care itself (Nyblade et al. 2017).

Tanzania is a country facing a lot of setbacks from; poverty, low level of education, poor infrastructures, high maternal mortality rates, and diseases. The country has realized the shortage of healthcare experts which is impacting the country very badly in achieving health-related MDG's. Adding to that the SRHR in African settings are not well communicated from a parent to a adolescents children, In line with previous research, the result in this study shows that students and parents are lacking in conversation about SRHR (Tume ya Kudhibiti Ukimwi Tanzania 2010).

Tanzania has been used its National Health Policy of 2017 which has a vision of achieving a target of a healthy community that serves effectively to individual needs and development. One of its mission is to improve the provision of adequate primary health services with better quality, reasonable, easy accessibility, inexpensive, sustainable, and hence gender-sensitive. The forefront target is enhancing the health and wellbeing of all people, emphasizing those who are at most risk of accessing health services and creating a more responsive health system to cater to the needs of the people and escalate life expectancy.

The well-arranged scheme of the policies, institutions, government strategies, and programs that exists upsurge the development of the health sector in Tanzania. The TNHP 2017 implementation anticipated to go hand in hand with the attainment of the 2025 National Development Vision, the Sustainable Development Goals 2030, the National Five Year Development Plan from the year 2016 and 2017 up to the year 2020 and 2022, and lastly the Health Sector Strategic Plan 2015 up to 2020 (MOHCDGEC 2017).

It has been targeted that by the year 2025, Tanzania has to attain a high quality of livelihood to all its citizens. I came together with achieving; good governance, peace, stability, and unity, increase the number of elites, and a good economy which will go in hand with sustainable growth. The TDV 2025 stands as a guiding torch for the attainment of sustainable enduring development. To accomplish it, TDV put an emphasis on the health sector so as to maintain Tanzanians wellbeing. The Five Years Development Plan (FYDP II) has a definite goal of making sure Tanzanians are healthy and able to go on with their socio-economic routines. All this is dependent on the urge of bettering the whole health system with regards to the total reformation of service provided to mothers and children. However, dangerous illness such as HIV/AIDS, and Malaria which at a great extent has become a major setback 
to mothers and children has to be combated at the same time solving the mystery of limited healthcare providers. Special input contains; harnessing the health and livelihood of Tanzanian; solidification of referral hospitals; reforming training centers, and tallying the accessibility of specialized amenities (MOHCDGEC 2017).

Tanzania as one of the developing countries in Africa has also committed to the Sustainable Development Goals (SDG's) 2030. Upholding good health and wellbeing is one of the forefront goals of the agreement. However, in Tanzania, specific developments have been made on increasing the wellbeing and life expectancy of its people. But on the other hand, women are still facing obstacles as only half of the women in developing countries have successfully benefited from the compulsory health care they needed, plans and continuous implementation are compulsory in Tanzania to realize the health services and especially SRHR to women. The target of the Health Sector Strategic Plan IV is to attend to all households by providing them with good health and social welfare services, meeting and accomplishing all the needs of its people in quality, and applying the efficient monitoring and evaluation of the service provided. Nevertheless, the HSSP IV goals include; improving the quality of the basic health care provision, setting a solution and providing essential services to the people and health centers in general, equal access to the health care services country wise by prioritizing the areas with a high rate of diseases, giving a particular emphasis on the struggling populations especially in areas which are vulnerable to diseases, reaching the high rate of return on investments by adopting modern management techniques and collaborate with partners of developments on solving the challenges on the health sector, encouraging community participation through increase collaborations when it comes to the improvements of health and social wellbeing of the Tanzanians. The health sector will collaborate with other sectors in making sure the inclusion of health promotion and health protection measures in several strategies, and policies available in other sectors (MOHCDGEC 2017).

Tanzanian government demonstrates its commitment to discourse sexual and reproductive health rights by being a signatory to several international agreements associated with Gender-Based Violence (GBV) and gender issues, to mention a few; The Convention on the Elimination of all Forms of Discrimination against Women (CEDAW) 1985, focusing on prohibiting the effects of discrimination, involving violence; the Beijing Platform for Action (BPA) 1995, The African Charter on Human and People's Rights on the Rights of Women, African Union's Maputo Plan of Action dealing with the Operationalization of the Universal Policy Framework for SRHR, and the SADC Protocol. Nevertheless, Tanzania has decided on main areas of concerns which have been operationalized through; National Strategy for Growth and Poverty Reduction (NSGPR) which labeled HIV/AIDS and gender as cross-cutting issues and also identifying the need to address gender violence as a public policy issue. The 1994 Cairo International Conference on Population and Development agreed on a perfect definition of reproductive health and therefore assign each Nation to make sure of the attainment of adolescent's health needs such as, the services and education which will enable them to deal with their sexuality in a positive and responsible approach.

On top of that, Tanzania has a set of policies and laws enacted to govern some areas and sectors but at the same time the impacts are different when considering gender, both men and women are impacted differently. At some point, the policies are even contradictory to other policies in place. In recent times Tanzania has enacted the new Law of Child Act to protect children's affairs, but on the other hand, there is the nonexistence of an impeccable National law that is particularly amended to stand against domestic violence and gender-based violence. The United Republic of Tanzania's constitution Article 13:6(e) approved in 1977, and revised in 2005, as it aligns with universal rights stated; "no person shall be subjected to torture or inhuman or degrading punishment or treatment". Nevertheless, the Sexual Offense Special Provisions Acts of 1998 which is supposed to cover all aspects of sexual offenses it does not recognize marital rape only if the couples are separated. This makes women vulnerable to sexual infections such as HIV/AIDS this adds the implication that gender-based violence has a direct link to HIV/AIDS (The Constitution of the United Republic of Tanzania 1998).

However, the existing laws which aim to protect women matters still have some loopholes. Unmarried women are facing several challenges like economic deprivation, and several GBV acts which are unrecognized in the laws. For instance, the Anti Human Trafficking Persons Act of 2008, doesn't allow forced labor on children and women, sexual exploitation, and forced marriages at the same time this policy has gaps as women and children still migrate from rural areas to urban in expectation of job, and good life. Human trafficking reports amplified 5 percent before the year 2000, up to 71 percent between 2006 and 2008. Hence the reported groups were; women, girls and, young males were reported as the main victims of human trafficking (Kamazima 2009). 
On the other hand, there is a law that instructs a voluntary HIV/AIDS test of the pregnant woman and the father of the unborn child. The HIV/AIDS Prevention and Control Act, 2008 instructed that when one partner test positive for HIV/AIDS he/she is responsible to inform his or her sexual partner or spouse, but due to the fear of rejection and diverse society misconception on HIV/AIDS patients makes this difficult. Very few partners voluntarily escort their spouses. (National Bureau of Statistics Tanzania \& ICF Macro 2011), in the TDHS 2010, 9 percent of women have come across and reported physical violence during their pregnancy period.

\section{Research Methods}

This particular study has been conducted by using a qualitative research approach, whereby ways of obtaining data like; document analysis (policies, strategies, charters, writings), data analysis, such as content analysis has been employed. Content analysis enables tis study to determine the presence of concepts and to descend the meanings within the writings. A review and reflection of different national and international laws and policies concerning SRHR in Tanzania are interpreted and discussed by incorporating the general justification and the author's points of view. A vast amount of data have been extracted from the TNHP, Sixth draft version, for External Consultations with Ministries, Departments, and Agencies, published on $24^{\text {th }}$ October 2017.

Specific policy objectives were analyzed, for instance the main objective of reducing the morbidity and mortality rate and increasing life expectancy to Tanzanians through provision of better health services. However, some commentary and previous studies have been incorporated, research by governments, civil societies, and scholars, published reports, articles will be referenced to accomplish this study. It's our firm belief that this review will be a milestone toward reviewing and amending the TNHP 2017 so as to cover the SRHR in Tanzania and that it will directly contribute positively to the achievement of other goals and targets including those related to health, gender equality, poverty, and education.

\section{Results and Discussion}

\section{SRHR in Tanzania}

The SRHR is unswervingly related to the human reproduction functions and associated complications linked to, pregnancy itself, STDs, GBV, FGM/C, inhuman cultural practices, family planning, VAC, cervical cancer, and infertility treatment. Concerning family planning, measures have been taken to uplift the service through providing couples with different methods like contraceptives which its coverage is monitored by the frequency rate. Nevertheless, inadequacy persists as limited strategies hinder the raise community awareness on Harmful Traditional Practices such as forced marriages, early marriages, $\mathrm{GBV}$, and FGM/C whereby the so-called traditional practices are still conducted especially in the remote areas. Similarly, there is a gap which is overlooked as GBV and VAC records have remained the leading encounter. Pregnant women are experiencing violence during pregnancy, the policy hasn't strategized directly on that category. The policy generalized GBV to women and didn't shatter it down to its various forms, such as physical, or verbal. It happens that women are facing GBV even at the time of pregnancy pregnant. When a woman is pregnant that's where the cruelest violence occurred. Most remarkably in the idea that major disease programs like HIV/AIDS and Malaria programs which are highly affecting a mother and a child inflict more demands on the current labor force without considering the additional supports needed to affect the plans against the diseases.

Nonetheless, on the implementation ground, which sets out the objectives of the plan and the activities linked to implementing this, there is a strategy to strengthen workforce practices, increase the number of health workers, and training of health workers. All these are vital in achieving the SRHR rights to women and the whole society, but the policy shows zero effort on empowering health workers even through training. There is also a mention of building a case to accommodate new and emerging health care, as well as introducing communal health care cooperatively with the primary health care but it's still not achieved. Irrespective of the changes made in the reproductive health area, solicitation of family planning to society has remained an obstacle. It has been noted that it is vital to provide a well-structured family planning scheme. Many countries in Asia such as Palestine have put a particular focus on matters related to family planning. According to Bosman et al., 2008 since the structure of the Palestinian Ministry of Health, their priority has been to women's health in the Palestinian Health Policy. In the year 1995, Palestinians witnessed an enormous milestone whereby the Directorate for Women's Health and Development was started, focused mainly on family planning (Bosmans et al. 2008). But in Tanzania the vice versa is true and the strategies seem unfruitful due to the existence of traditional misconceptions, and myths; thus resulted in low male involvement on issues concerning reproductive health, insufficient health practitioners, GBV, Gender norms, also a changeable need of family planning methods led to a 
mix-up of health facilities in place and the community itself. Generally, unsatisfactory knowledge to the public on various sexual and reproductive measures has led to slow improvements in the reproductive health services area. (MOHCDGEC 2017).

However, the provision of health care especially in remote areas is still limited in regards to facilities and enough health care practitioners. Generally, the whole system of the health sector is dependent on the national budget, and local government tax collection. The community health fund is considered as the means to mobilize society involvement in supporting and valuing health services by protecting their health as well. Things like health insurance are considered as the helper to make sure the employees in the formal sectors are well protected.

\section{SRHR and the gaps}

Tanzania made a critical attempt in the realization of the Millennium Development Goals (MDG) created by the UN, to combat diseases, to eradicate poverty, and reducing the mortality rate. These remain important as well in the efforts to achieve SRHR in the countries like Tanzania which is struggling to solve the challenges facing the health sector to achieve quality and easy accessibility of the services. Foremost, Tanzania has a critical shortage of health professionals which affects its ability to make changes in the health sector and to achieve the provision of SRHR.

However, as Tanzania's adopted some of the key agreements related to SRHR, the Cairo's Program of Action of the International Conference on Population Development of the year 1994 defined reproductive health as "a state of complete physical, mental and social well-being and not merely the absence of disease or infirmity, in all matters relating to the reproductive system and its functions and processes." (United Nations General Assembly 1995). Besides, it's known that reproductive health care means having access to quality information and services (UN 2018). The TNHP 2017, recognizes that reproductive health services include human reproductive function-related complications and disease as well starting from; pregnancy, HIV/AIDS, VAC, FGM/C, STDs, prevention and treatment of cervical cancer, bad traditional practices, and family planning (MOHSW 2017). Nevertheless, the Tanzania government has continuously provided education concerning sexual and reproductive health services; such as education for prenatal and post-natal care, and also safe delivery. Information, counseling, services as the provision of access to contraceptives method has been well delivered.

Women's SRHR are related to several rights which are encompassed in general human rights, the right to free speech, right to health, right to health, right to education, the rights to be free from torture, and right to be protected from discriminations. CEDAW committee has specified that women's rights to health includes their sexual and reproductive health. This implies that every country have the responsibility to provide, respect, and protect all the rights concerning women's sexual and reproductive health. The Tanzania's reproductive health services includes the related diseases, with a particular emphasis on pregnancy, Sexual Transmitted Diseases (STD's) family planning, GBV, violence toward children (VAC), FGM/C, providing special education and information about cervical cancer, treating infertility, and also reducing the extent traditional practices.

Despite the few strategies concerning women in the TNHP 2017, violence toward women and the denial of their SRHR are frequent and unsolved due to the gaps that existed in the policy itself. These take many forms including the insufficiency of access to services that only women require. For instance, in safe delivery, women are still vulnerable when it comes to pregnancy and its accompanying complications. In a rural setting, the protracted home delivery trend is observed, due to some traditional practices and believes, poor education, and also extreme poverty makes women do the delivery at home under the care of local midwives with little knowledge and limited tools which endangers the life of both mother and a child.

However, the poor quality of health services that impacted women the most is still a mystery. On the other hand, the policy didn't cover the issue of the performance of procedures related to women's reproductive and sexual health in absence of their bits of knowledge. Services like sterilization, virginity examination, and in some circumstances forced abortion interprets that women are lacking control over their bodies when it comes to fertility, sexuality, and relationships and that the individuals are not allowed to consider their own choices and decisions.

Women's SRHR are at greater risks when it comes to hindrances such as FGM/C, forced and early marriage, and also GBV. These challenges have not been strategized or stipulated in the policy, which leaves a large gap between women and the attainment of the SRHR. Nevertheless, the Beijing platform for action states that "the human rights women include their right to have control over and decide freely 
and responsibly matters related to their sexuality, including sexual and reproductive health, free of coercion, discrimination, and violence". At the same time, the CEDAW committee recommendation number 24, states that both states should prioritize the controlling of unwanted pregnancies through the provision of enough education and ensuring easy accessibility of information concerning family planning and sex education, which has not stipulated or partially mentioned in the policy.

However, apart from matters like marital rape, access to SRHR information such as hygiene educations to girls/adolescents at schools in remote areas to be left behind, also the accessibility to sanitary pads to village areas has also been a challenge and still, the policy didn't put a particular focus on it. However, violations of women's sexual and reproductive health rights are often deeply engrained in societal values about women's sexuality, and definitely, the health policy is to be blamed as people lack enough education on SRHR. Patriarchal atmosphere entails the perception that women are being valued with regards to their capability to reproduce. However early pregnancies, early marriages, and forced marriages still distress women. As an effort of having male offspring, repeated, unplanned, and pregnancies spaced very close are continuing without total agreements with the woman. This carries an overwhelming impact on women's health coming along with serious implications. Women are also subjected to several human rights violations, at the same time being accused of infertility, bringing STDs to marriages, etc.

Nonetheless, it has been renowned that SRHR is a set of rights that universal noticeable but in Tanzania that has been proved otherwise, as other groups are being left behind from the National Health Policy itself. The Constitution of Tanzania prohibits any Tanzanian to be discriminated against. Article 613 (1) states that; "All persons are equal before the law and are entitled, without any discrimination, to protection and equality before the law" (The Constitution of the United Republic of Tanzania 1998), but it has been comprehended differently to the LBTQ group. Recent suggestions show that the risk of acquiring HIV is much higher in homosexuals than in people who engage in heterosexual sex. Currently, very little is known, mentioned, or discussed in the National Health Policy about the wide-ranging risks of STD's among Lesbian, gay, bisexual, transgender people, and queer (LGBTQ) in the country, however, there is limited advocacy towards the group's inclusion in HIV and STD's prevention programs.

However, the TNHP 2017 hasn't fully contemplated the adolescent's health and rights while the adolescent's girl's health and SRHR have to be given a special focus. According to Chandra-Mouli et al. (2015), adolescents weigh 23 percentage of the whole burden of disease in society and that's because of childbirth, early marriages forced marriages, and pregnancy. Childbearing has a direct link to maternal and mortality rates due to illegal and unsafe abortions. Maternal is the leading cause of death among adolescent girls, unsafe abortion happened each year, approximately $15 \%$ are adolescent girls. Nevertheless, an estimate of over 1 million young population from the age of 15 to 24 years of age are infected with HIV/AIDS each year which accounts for 41 percent of the record of the new infections on their age gap. Universally, young women constitute about $60 \%$ of the whole population of young women who lives with HIV/AIDS infections. In sub-Saharan Africa reported to as approximately as high as $72 \%$ (Chandra-Mouli et al. 2015).

In addition, above $78 \%$ of the young women population resides in Africa and Asia, all together they make a total of $30 \%$ and amongst the two-thirds of the young women are in marriage (Shaw 2009). And specifically in Africa and Asia is where the most prevailed harmful traditional practices protrude and therefore more attention is needed. In consideration of all the aforementioned facts, it's vividly that the adolescent population needs a special focus due to the risks they are in. The TNHP 2017 left behind adolescents by showing fewer efforts on their health rights and services. A total lack of tangible adolescent's health rights and services strategies has been observed, and by saying so a special eye and their inclusiveness is vital.

Women and adolescents with a disability, TNHP 2017 fail to recall about SRHR to people with disability. Apart from striving to achieve SRHR in general, women and adolescents are in a huge burden when it comes to accessing the scarcer available SRHR services. The insufficiency accessibility is higher to adolescents, according to Mesiäislehto et al. (2021) discrimination hinder the obtainment of SRHR services through different times of need, the friendly approach of the health care providers in the center for the accessibility which has been proved otherwise. Whatsoever in TNHP 2017, there is neither the mention nor the friendly/affectionate service provided to women and adolescents with disabilities. Generalization of the SRHR in the policy makes achieving it more solid as some groups require distinctive consideration when it comes to the access of important services such as SRHR. The Mesiäislehto et al. (2021) study proposed that an affectionate and friendly environment should be created and encouraged between the health care providers and disabled women and adolescents when they are in the careseeking phase (Mesiäislehto et al. 2021). 


\section{Conclusion}

Violence toward women and bad traditional practices have been the main setbacks toward the realization of SRHR. The denial of SRHR takes many forms including the shortage of crucial health services, such as; information concerning reproductive matters, issues such as family planning, and inadequate care during pregnancy. Safe delivery has also been a challenge, women are still vulnerable when it comes to pregnancy and its complications. In rural areas, the situation is worse, as the lack of health services results in in-home delivery with the help of local midwives with limited tools which endanger the life of mother and child.

However, fragile health services affect women to a greater extent and remain a big trial in Tanzania. The policy itself keeps SRHR at a greater risk as not mentioning or placing an emphasis on issues like; marital rape, FGM/C, forced and early marriages. Legally, marital rape is considered as an offence in very limited circumstances. GBV cases are high and the perpetrators left unpunished while many pending cases concerning violence are piling up (HEARD 2015). These encounters have not been strategized or stipulated in the policy, which consent a gap between women and the attainment of the SRHR. Challenges facing SRHR are the results of inadequate legal and policy framework combined with the ineffective implementation of the strategies in place. Therefore, to achieve SRHR the government has to be held accountable and both parties has to work together, the policy has to be reviewed to cover the gaps, and at the same time strengthening the operation by developing an effective and supportive strategies framework that can assure the realization of SRHR, on the other hand, the adoption other several advanced non-bias policies for the execution of SRHR.

Contrariwise, SRHR can be attained when gender equality is in place, an unequal status between men and women in society makes women's life more complicated. The majority has both lower financial and social status, this makes women and girls extra vulnerable to, deprived health services, and mortality rate. Vividly, gender inequality has a direct link to the narrow SRHR. This study succeeded to show how women's sexual and reproductive health care system is wrecked and needs to be amended. This study will be another milestone toward reaching better access to a healthcare system that is inclusive to both men and women, meanwhile making a step toward reaching gender equality in Tanzania and helps on achieving the Agenda for Sustainable Development by the year 2030. Due to the highlighted gaps, it's wise enough to recheck specifically policies that have to be reviewed and amended to meet the needs of both men and women in society.

Evidently, in Tanzania Women's SRHR and wellbeing are highly influenced by harmful gender norms in our societies, they even shape behaviors that bring direct impacts to the SRHR. However, since policy formulation is an ongoing process, it's my hope that this study will benefit policymakers to create better policies in regards to the gaps specified. And that the policy will adhere to the attaining of better healthcare which will be inclusive to both men and women, meanwhile making a step on reaching gender equality in Tanzania. It's also expected that this study will be useful for the next reviews, which will be undertaken by other researchers on demanding amendments, or implementation of Tanzania health policy to meet both men's, women's, and girl's needs. It's high time for the Government, Nongovernmental organizations, and legal institutions to work together to solve the uncertainties, and foreseeing sustainable, and long-term solutions towards the matter.

Nevertheless, in this time of COVID-19 pandemic, the SRHR are also traumatized, as COVID-19 upsurges the mortality rates and so does SRHR, by considering the importance of SRHR in our social life and health in general SRHR cannot be disremembered especially during the time of tragedies. As far as the government is focusing on combating the disease the responsible authorities have to continue with the execution of strategies to diminish SRHR.

On the other hand, young women's health rights and services are not sufficiently considered. Especially in African settings adolescents weigh a burden of challenges rated from diseases to childbirth, FGM/C, VAC, early marriages and forced marriages, pregnancy, and several harmful practices. In consideration of all the aforementioned facts, it's vividly that the adolescent population needs a special focus due to the risks they are in. The TNHP 2017 left behind adolescents by showing fewer efforts on their health rights and services. A total lack of tangible adolescent's health rights and services strategies has been observed, and by saying so a special eye and their inclusiveness is vital. Lastly, it's high time now for the Governmental and Non-governmental organizations to come as one and responds to SRHR through better policy frameworks, implementation of the existing strategies, promoting accountability in SRHR, funding initiatives, and new strategy creations. 


\section{References}

Alemu T \& Fantahun M (2011) Sexual and reproductive health status and related problems of young people with disabilities in selected associations of people with disability, Addis Ababa, Ethiopia. Ethiopian Medical Journal 49 (2):97-108.

Bosmans M, Nasser D, Khammash U, Claeys P \& Temmerman M (2008) Palestinian women's sexual and reproductive health rights in a longstanding humanitarian crisis. Reprod Health Matters 16 (31):103-111.

Boydell V, Schaaf M, George A, Brinkerhoff D W, Van Belle S \& Khosla R (2019) Building a transformative agenda for accountability in SRHR: Lessons learned from SRHR and accountability literatures. Sexual and Reproductive Health Matters 27 (2):64-75.

Chandra-Mouli V, Svanemyr J, Amin A, Fogstad H, Say L, Girard F \& Temmerman M (2015) Twenty years after international conference on population and development: Where are we with adolescent sexual and reproductive health and rights? Journal of Adolescent Health 56 (1):1-6.

Darroch JE, Frost JJ \& Singh S (2001) Teenage Sexual and Reproductive Behavior in Developed Countries. New York: The Allan Guttmacher Institute.

Devries KM, Kishor S, Johnson H, Stöckl H, Bacchus L, Garcia-Moreno C \& Watts C (2010) Intimate partner violence during pregnancy: Prevalence data from 19 countries. Reproductive Health Matters 18 (36):1-13.

García-Moreno C, Jansen HA, Ellsberg M, Heise L \& Watts C (2005) WHO Multi-Country Study on Women's Health and Domestic Violence Against Women: Initial Results on Prevalence, Health Outcomes and Women's Responses. Geneva: World Health Organization.

Global Health Workforce Alliance (2013) MLHWs Country Case Studies: Annex 5. Tanzania. MLHWs Country Case Studies, 1-19. [Accessed 17 January 2021]. who.int/workforcealliance/knowledge/ resources/MLHWCountryCaseStudies_annex5 Tanzania.pdf.

Government of Sweden (2016) Strategy for Sexual and Reproductive Health and Rights (SRHR) in SubSaharan Africa. Stockholm: Government of Sweden.

HEARD (2015) Country factsheet: Tanzania sexual and reproductive health and rights. [Accessed 10 January 2021]. http://www.heard.org.za/wp-content/uploads/2015/11/Zimbabwe-country-factsheet.pdf.

Kamazima SR (2009) Human trafficking baseline assessment in Tanzania: Findings from selected regions. A Report published for International Organization for Migration 7-8.

Mesiäislehto V, Katsui H \& Sambaiga R (2021) Disparities in accessing sexual and reproductive health services at the intersection of disability and female adolescence in Tanzania. International Journal of Environmental Research and Public Health 18 (4):1-14.

MOHCDGEC (2017) The united republic of Tanzania, Ministry of health, community development, gender, elderly and children. The National Health Policy 2017, Sixth Draft Version, for External Consultations with Ministries, Departments, and Agencies, $24^{\text {th }}$ October 2017.

National Bureau of Statistics Tanzania \& ICF Macro (2011) Tanzania Demographic and Health Survey 2010. Dar es Salaam: NBS \& ICF Macro Press.

Ngilangwa DP, Rajesh S, Kawala M, Mbeba R, Sambili B, Mkuwa S, Noronha R, Meremo AJ \& Nyagero $\mathrm{J}$ (2016) Accessibility to sexual and reproductive health and rights education among marginalized youth in selected districts of Tanzania. The Pan African Medical Journal 25 (2):1-7.

Nyblade L, Stockton M, Nyato D \& Wamoyi J (2017) Perceived, anticipated and experienced stigma: Exploring manifestations and implications for young people's sexual and reproductive health and access to care in North-Western Tanzania. Culture, Health and Sexuality 19 (10):1092-1107.

Schaaf M, Boydell V, Van Belle S, Brinkerhoff DW \& George A (2020) Accountability for SRHR in the context of the COVID-19 pandemic. Sexual and Reproductive Health Matters 28 (1).

Shaw D (2009) Access to sexual and reproductive health for young people: Bridging the disconnect between rights and reality. International Journal of Gynecology \& Obstetrics 106 (2):132-136.

Sundby J (2006) Young people's sexual and reproductive health rights. Best Practice \& Research Clinical Obstetrics \& Gynaecology 20 (3):355-368.

Tume ya Kudhibiti Ukimwi Tanzania (2006) Mpango uendeshaji wa kijinsia kwa ajili ya mwitikio wa VVU. Dar es Salaam: Jamhuri ya Muungano wa Tanzania.

Tajfel H \& Turner JC (1986) The Social Identity Theory of Intergroup Behavior. In: Worchel S \& Austin WG (ed). Psychology of Intergroup Relations. Chicago: Nelson-Hall. 7-24.

The Constitution of the United Republic of Tanzania (1998) The Constitution of the United Republic of Tanzania: Amendments.

Tull K (2019) Evidence on Family Planning Use in Young People of Tanzania. Brighton: Institute of Development Studies.

Tull K (2020) Maternal and Sexual Reproductive Health Situation in Tanzania. Brighton: Institute of Development Studies. 
Turner JC (1978) Social Comparison, Similarity and Ingroup Favouritism. In: TH (ed). Differentiation between Social Groups: Studies in The Social Psychology Of Intergroup Relations. London: Academic Press. 235-250.

Turshen M \& Turshen M (2020) Sexual and reproductive health and rights. Women's Health Movements, 191-229.

UN (2018) Reproductive Health Policies 2017. Economic \& Social Affairs, Data Booklet. Sweden: United Nations.

UNESCO (2013) Addressing the links between gender-based violence and HIV in the Great Lakes region: Background Information on GBV and HIV. Regional Workshop-15-16th July 2013 Dar es-Salaam, Tanzania,1-21. [Accessed 20 December 2020]. unesco.org/new/fileadmin/ MULTIMEDIA/HQ/BSP/GENDER/PDF/HIVGBVbackgroundreport.pdf.

United Nations General Assembly (1995) Principle 1 and Principle 4, respectively, of the ICPD Programme of Action, uphold human rights and gender equality and equity and women's empowerment. In Report of the International Conference on Population and Development. A/94/10/18. Programme of Action (Issue September 1994). [Accessed 21 December 2020]. https://www.un.org/en/ development/desa/population/events/pdf/expert/27/SupportingDocuments/A_CONF.171_13_ Rev.1.pdf.

Yngheden E \& Sandqvist J (2019) Educating students about sex is like giving them a gift, without being allowed to open it: A study about students' attitudes towards Sexual and reproductive health and rights education in Moshi, Tanzania. Dissertation, Malmö University, Swedia. 